\title{
Should I stay or should I go now?
}

\author{
Tony Delamothe deputy editor
}

The BMJ

The United Kingdom is facing its most important decision so far this century. To help UK readers of The BMJ decide how to vote in the referendum on leaving the European Union ("Brexit") on Thursday 23 June, we have been publishing a series of articles looking at the effects of Brexit on public health, the drug industry, finance, trade, employment law and doctors' working conditions, science and research, and the NHS. They're collected on our website at bmj.com/brexit.

Our intention was to remain scrupulously even handed. But as the series progressed we concluded that the arguments for remaining in the EU were overwhelming and that now was not the time for balance (doi:10.1136/bmj.i3302). We're not alone: no prominent UK medical, research, or health organisation has sided with Brexit. In addition, a slew of health experts has come out against Brexit, with Sarah Wollaston, chair of the parliamentary health select committee, an 11th hour convert to the Remain cause (doi:10.1136/bmj.i3295).

Our patch is health and medicine, but we don't pretend that consideration of these will swing the vote. That's despite one of the main arguments of the Brexit camp being that the UK's weekly contribution of $£ 350 \mathrm{~m}$ ( $€ 440 \mathrm{~m}$; $\$ 500 \mathrm{~m}$ ) to the EU could be better spent on the NHS (a "knowingly deceitful figure," says Wollaston).

Many of the crucial arguments for remaining in the EU are economic, and the outfits that know about such things are unequivocal. In its cover feature on the issue the Economist magazine damned Brexit as "Bad for Britain, Europe and the West" (http://econ.st/1S3NPJQ). The Financial Times' senior commentator, Martin Wolf, concluded, "Those in favour of leaving offer fantasies of damage done by staying and of opportunity opened by departure." Instead, "the rational thing to do is for the UK to continue to enjoy its unique arrangement, which has brought it the advantages of membership with so few of the disadvantages" (http://bit.ly/1OnjdIy).

Whatever the outcome, this Editor's Choice will be my last. I'll be retired by the time you read it. If the referendum results in Brexit I'll be off too. As a Commonwealth immigrant married to a German, I've vowed to sell up and move to my wife's house in rural Germany. After 44 happy years here, I couldn't bear to witness the fallout for my adopted country of such mindlessly inflicted self harm. 